Polineuropatia wywołana chemioterapią (chemotherapy-induced polyneuropathy - CIPN) jest częstym powikłaniem leczenia przyczynowego nowotworów. Głównymi lekami pozostają leki przeciwpadaczkowe i przeciwdepresyjne, jednak opioidy stanowia integralną część terapii złożonej w tej jednostce chorobowej. Artykut jest próbą oceny aktualnej wiedzy na temat roli opioidów w leczeniu CIPN.

Brak badań dotyczących stosowania opioidów w CIPN powoduje, że wnioski na temat ich skuteczności można wysnuwać jedynie per analogiam. $\mathrm{Na}$ podstawie dostępnej literatury dotyczącej doświadczeń modelowych i obserwacji klinicznych można stwierdzić, że opioidy są ważnymi składnikami w terapii złożonej w przypadku bólu neuropatycznego, a zatem skuteczne również podczas leczenia CIPN. Powinowactwo do receptorów błonowych jest jednym z warunków działania analgetycznego leków opioidowych. Różnorodność tych białek i ich podklas warunkuje różną skuteczność ich ligandów, co uzasadnia zarówno rotację opioidów, jak i ich łączenie. Na podstawie badań modelowych i obserwacji klinicznych stwierdzono, że spośród czystych ago nistów receptora opioidowego najsilniejsze działanie analgetyczne w bólu neuropatycznym wykazał oksykodon.

Słowa kluczowe: polineuropatia wywotana chemioterapią, ból neuropatyczny, opioidy, efekty uboczne.

\section{Opioidy w leczeniu polineuropatii wywołanej chemioterapią}

\author{
Krzysztof Brzeziński, Roman Chwedorowicz
}

Instytut Medycyny Wsi w Lublinie

\section{Wstęp}

Rozwój onkologii ma za zadanie przede wszystkim zwiększenie skuteczności leczenia poprzez prowadzenie nowych form chemioterapii, radioterapii, hormonoterapii i technik operacyjnych. Dzięki temu można zahamować rozwój choroby nowotworowej, jak również zwiększyć wyleczalność i przeżywalność pacjentów. Jedną z konsekwencji postępu leczenia jest stosowanie leków coraz bardziej toksycznych, działających na wszystkie komórki organizmu. Efekty uboczne leczenia przeciwnowotworowego są zależne głównie od specyficznego działania leku i mają swą lokalizację w różnych narządach [1]. Prognozy wskazują na coraz większą liczbę rozpoznawanych przypadków nowotworów, więc przy zwiększonej wyleczalności można spodziewać się również większej liczby pacjentów cierpiących z powodu efektów ubocznych leków [2]. Niniejszy artykuł stanowi próbę przedstawienia problemu stosowania opioidów w dość często spotykanym zespole polineuropatii wywołanej chemioterapią (chemotherapy-induced polyneuropathy-CIPN).

Opracowania poświęcone problemowi neuropatii najczęściej klasyfikują tę jednostkę chorobową, wyróżniając pierwotne przyczyny powstania uszkodzenia nerwów [3-8], przy czym problem uszkodzenia nerwów w przebiegu chemioterapii traktowany jest raczej marginalnie. Najlepiej zbadane i opisane są polineuropatia w przebiegu cukrzycy i neuralgia popółpaścowa, dlatego również bardzo często doświadczenia zdobyte podczas leczenia tych zespołów odnoszone są do CIPN [5, 7, 9, 10].

Publikacje dotyczace medycyny opartej na faktach (Evidence Based Medicine - EBM) nie zawierają wzmianki o patofizjologii i leczeniu CIPN [7, 10, 11], a w opracowaniach omawiających określone grupy chemioterapeutyków można znaleźć informacje pozwalające na ocenę tego problemu ograniczoną do wybranej grupy leków, nie zaś problemu w całości [12, 13]. Finnerup i wsp. sugerują, że jeżeli nie mamy wiedzy dotyczącej patofizjologii i sposobów zapobiegania opisywanemu zjawisku, należy dążyć przynajmniej do znalezienia sposobu leczenia uciążliwych objawów [7].

\section{Neuropatia toksyczna}

Jedną z przyczyn występowania patologii obwodowego układu nerwowego jest działanie toksyczne różnych środków chemicznych, stąd nazwa neuropatia toksyczna (ang. toxic neuropaty - TN). Leki z grupy chemioterapeutyków również należy zaliczyć do substancji toksycznych, zatem CIPN jest jedną z form TN [14]. Należy zwrócić uwagę na to, że bardzo często CIPN uważana jest za zespół chorobowy mający jednorodną etiologię i symptomatologię. W istocie jedynie objawy CIPN w postaci uczucia drętwienia, mrowienia, bólu o charakterze palącym, piekącym są cechą wspólną dla wszystkich polekowych zespołów bólowych, natomiast patomechanizm tego zjawiska jest zróżnicowany. Badania nad opisywanym problemem trwają nadal i przynajmniej w przypadku niektórych leków można już opisać patomechanizm uszkodzenia nerwu [14, 15]. Mechanizm uszkodzenia układu nerwowego w przebiegu CIPN zostanie dokładnie omówiony w oddzielnym artykule. Mimo że znana jest neurotoksyczność 
tych preparatów i częstość wywoływania CIPN, nie znaleziono dotąd skutecznych metod zapobiegania temu zjawisku [5, 14, 16, 17].

Występowanie zmian w układzie nerwowym spowodowanych chemioterapią w większości przypadków jest zależne od dawki zbiorczej leku, natomiast początek choroby może nastąpić zarówno w trakcie leczenia, jak i dopiero po jego ukończeniu. Niektóre czynniki charakterystyczne i częstość występowania CIPN zestawiono w tabeli 1, chociaż dane na temat częstości występowania tego zjawiska nie są jednoznaczne.

\section{Leczenie polineuropatii wywotanej chemioterapią}

Zasady leczenia bólu neuropatycznego zostały skodyfikowane w wytycznych opublikowanych przez różne towarzystwa naukowe i w większości oparte zostały na EBM. Wszystkie dostępne wytyczne polecają leki przeciwdepresyjne i przeciwpadaczkowe jako najbardziej skuteczne, a co za tym idzie - zalecane jako leki pierwszego rzutu, a opoidy są klasyfikowane na drugim miejscu [4, 6, 18, 19]. Polecane jest również leczenie uzupełniające, polegające na stosowaniu miejscowym lignokainy lub kapsaicyny w postaci plastrów. Występują wprawdzie pewne kontrowersje co do zasadności wprowadzenia do leczenia i sposobu dawkowania [18, 19], lecz problemy te przekraczają zakres niniejszego artykułu i wymagają osobnego omówienia.

Jak wspomniano na początku, brakuje jednoznacznych danych, pochodzących z badań klinicznych z randomizacją, klasyfikujących opioidy używane do leczenia bolesnej neuropatii spowodowanej chemioterapią. Stosowanie tych leków jest różnie traktowane przez autorów wytycznych. Przyczyną jest sama istota omawianego zespołu bólowego, ponieważ należy traktować go jako ból neuropatyczny mieszany. Znacznie łatwiej opracować algorytmy dotyczące wybranej jednostki chorobowej o poznanej i zdefiniowanej etiologii i patogenezie, jak neuralgia popółpaścowa, polineuropatia cukrzycowa czy neuralgia trójdzielna. Niektóre wytyczne $[8,12]$ zakładają wprowadzanie do leczenia jedynie tramadolu, podkreślając jednocześnie, że silne opioidy powinny być traktowane jako leki alternatywne ze względu na swoje działania uboczne.

Wprowadzenie do leczenia opioidów w przypadku, kiedy przyczyną choroby jest pierwotne uszkodzenie ośrodkowego lub obwodowego układu nerwowego, może budzić kontrowersje ze względu na opisane wyżej problemy. Jest to oczywiście dyskusyjne, najczęstszą przyczyną oporów zarówno ze strony pacjenta, jak i lekarza nie są bowiem możliwości zaburzeń układu hormonalnego czy domniemany wpływ na układ immunologiczny lub hiperalgezja wywołana opioidami, ale głównie obawa przed uzależnieniem [20]. Mechanizm ten jest tak silny, że nawet część lekarzy stosujących te leki w codziennej praktyce, niechętnie włącza je do leczenia w przypadkach tzw. bólu nienowotworowego [21]. W przypadku choroby nowotworowej bardzo często chory otrzymuje już w leczeniu opioidy, gdyż odczuwa inne dolegliwości bólowe, związane z chorobą zasadniczą wymagające stosowania rutynowo leków wg drabiny analgetycznej.

Decyzja kliniczna w przypadku leczenia pacjentów w takiej sytuacji ma zupetnie inną wagę, bo nie skupia się na problemie „Czy włączyć opioid?”, ale „Jaki opioid będzie w tym przypadku skuteczny?”. Należałoby więc spróbować znaleźć odpowiedź na dwa podstawowe pytania:

1. Czy mamy w tym momencie dostatecznie jasne dowody, aby rozpocząć leczenie opioidem, jeżeli można spodziewać się wystąpienia CIPN?

Tabela 1. Częstość występowania i cechy charakterystyczne przebiegu CIPN. Na podstawie Paice 2011

\begin{tabular}{|c|c|c|}
\hline Lek & Częstość występowania CIPN (\%) & Cechy charakterystyczne \\
\hline karboplatyna & $5-20$ & najczęściej przy dużych dawkach \\
\hline cisplatyna & $30-100$ & $\begin{array}{l}\text { zależne od dawki, może wystąpić z opóźnieniem, często występuje deficyt } \\
\text { sensoryczny i motoryczny }\end{array}$ \\
\hline oksaliplatyna & $\begin{array}{l}85-95^{a} \\
15-20^{b}\end{array}$ & parestezje i dyzystezje wywołane zimnem w obrębie dłoni i stóp \\
\hline bortezomib & $31-55$ & $\begin{array}{l}\text { CIPN jest powodem do przerwania leczenia; zależna od dawki sumarycznej; } \\
\text { może zwiększyć się po kilku miesiącach od zaprzestania leczenia; dołączają się } \\
\text { zaburzenia chodzenia }\end{array}$ \\
\hline $\begin{array}{l}\text { docetaksel } \\
\text { paklitaksel } \\
\text { paklitaksel związany } \\
\text { z albuminami }\end{array}$ & $\begin{array}{l}11-64 \\
57-83 \\
73\end{array}$ & $\begin{array}{l}\text { symetryczne, bolesne parestezje w zakresie dłoni i stóp; ma tendencję do roz- } \\
\text { szerzania się na podudzia; osłabienie kończyn prowadzące do ataksji; dołączają się } \\
\text { zaburzenia chodzenia, zwykle mijają po 1-3 miesiącach, ale mogą również pozostać }\end{array}$ \\
\hline $\begin{array}{l}\text { winblastyna } \\
\text { winkrystyna } \\
\text { windezyna } \\
\text { winorelbina }\end{array}$ & $\begin{array}{l}30-47 \\
11-60 \\
30-47 \\
30-47\end{array}$ & $\begin{array}{l}\text { symetryczne, bolesne parestezje w zakresie dłoni i stóp; ma tendencję } \\
\text { do rozszerzania się na podudzia; może wystąpić neuropatia w obrębie czaszki; } \\
\text { dołączają się zaburzenia chodzenia, częste opadanie stopy, zmiany w układzie } \\
\text { autonomicznym (20-30\%) }\end{array}$ \\
\hline iksabepilon & $20-63$ & bolesne parestezje i uczucie palenia, ustępuje po 4-6 tygodniach \\
\hline $\begin{array}{l}\text { lenalidomid } \\
\text { talidomid }\end{array}$ & $\begin{array}{l}10-23 \\
25-83\end{array}$ & $\begin{array}{l}\text { symetryczne, bolesne parestezje w zakresie dłoni i stóp, pieczenie i drętwienie, } \\
\text { ataksja sensoryczna, zaburzenia chodzenia }\end{array}$ \\
\hline
\end{tabular}

$a_{W}$ czasie trwania infuzji, ${ }^{b}$ dziatanie dtugoterminowe 
2. Które z czystych agonistów receptora $\mu$ powinny być używane w terapii skojarzonej, jeżeli mamy do czynienia z rozwiniętą formą neuropatii?

\section{Opioidy w polineuropatii wywołanej chemioterapią}

Skuteczność czystych agonistów receptora $\mu$, oceniana cyklicznie w badaniach Finnerup dotyczących bólu neuropatycznego, nie zmieniła się w sposób istotny pomiędzy rokiem 2005 a $2010[6,7]$ i jest oceniana bardzo wysoko. Współczynnik NNT (number needed to treat) dla tej grupy leków w ciągu ostatnich 5 lat pozostał na poziomie 2,6 (1,7-6,0), mimo że ukazały się kolejne wyniki badań klinicznych z randomizacją. Wskazuje to na wysoką skuteczność opioidów w leczeniu bólu neuropatycznego praktycznie we wszystkich jego postaciach. Ważne jest również, że współczynnik NNH (number needed to harm) pozostał na dość wysokim poziomie 17,1 (9,9-66), co świadczy o tym, że leki te są nadal uważane za stosunkowo bezpieczne. Podobne wnioski można wyciągnąć na podstawie prac dotyczących stosowania tramadolu, przy czym w tym przypadku stwierdzono nawet zwiększenie się NNH z 9,0 (6-18) do 13,3 (8,8-28). Jednak sama autorka zwraca uwage na to, że zmiany, o których mowa, stwierdzono na podstawie zaledwie 2 nowych publikacji na temat silnych opioidów i 3 na temat tramadolu. W dodatku (jak wspomniano na początku) prace dotyczyły jednostek chorobowych innych niż bolesna neuropatia spowodowana chemioterapią, więc wnioski w odniesieniu do opisywanej jednostki chorobowej można wyciągać jedynie przez analogię.

Eisenberg i wsp. [22, 23] poddali analizie publikacje dotyczące opioidów w leczeniu różnych zespołów bólu neuropatycznego, z których wynika, że najczęściej badane były alfentanyl, morfina i oksykodon. Opracowanie to nie wnos bezpośrednich danych do naszych rozważań, ponieważ po pierwsze żadna z publikacji nie dotyczy CIPN, po drugie zaś leki te porównywano z placebo - brakuje porównania konkretnych leków. Na zasadzie analogii można założyć, że skoro wymienione leki są skuteczne w polineuropatii cukrzycowej, neuralgii po przebytym półpaścu i bólu po udarze mózgu, można spodziewać się również ich działania w CIPN. Autorzy podkreślają, że stwierdzono, iż opioidy są bardziej skuteczne w neuropatii obwodowej, zmniejszając alodynię dotykową i wywołaną zimnem, co również może sugerować ich skuteczność w CIPN. Autorzy, analizując stosowanie opioidów w innych niż CIPN wskazaniach, opatrują swoje stwierdzenia zastrzeżeniem, że konieczne są dalsze badania w tym kierunku.

Ostatnio ukazały się zarówno opracowania systemowe, jak i wytyczne towarzystw naukowych traktujące stosowanie silnych opioidów jako integralną część terapii neuropatii w przebiegu choroby nowotworowej. Wprawdzie autorzy tych publikacji podkreślają brak literatury dotyczącej CIPN, niemniej jednak leki te włączają do rutynowej terapii [24-26]. Podobne sugestie zawiera praca Dzierżanowskiego i Ciałkowskiej-Rysz [27]. Autorzy (zwracając również uwagę na brak piśmiennictwa dotyczącego CIPN) podkreślają, że stosowanie opioidów może być jednym ze sposobów leczenia tego zespołu bólowego.

\section{Wybór opioidu}

Wiedza na temat mechanizmu działania opioidów zwiększyła się znacznie podczas ostatnich dziesięcioleci. Dzięki temu łatwiej jest dobrać najskuteczniejszy lek zarówno pod względem jego siły działania, ewentualnych objawów niepożądanych, jak i szczególnych sytuacji klinicznych, w których może się okazać bardziej skuteczny [28, 29].

Kluczowe znaczenie ma w tym przypadku znajomość budowy i fizjologii receptorów opioidowych i związanych z nimi białek $\mathrm{G}$. Wymienione struktury błonowe charakteryzują się dużą zmiennością, zależną m.in. od ekspozycji na egzogenne ligandy. W tym artykule rozpatrujemy problem użycia agonistów receptora opioidowego, chociaż istnieją sugestie dotyczące możliwości stosowania również ago-antagonistów.

Występowanie oporności komórek układu nerwowego na działanie analgetyczne opioidów jest spowodowane m.in. zjawiskami internalizacji i dimeryzacji receptorów błonowych, jak również znacznym polimorfizmem białka G odpowiedzialnego za ich aktywność wewnątrzkomórkową [30].

Internalizacja polega na „zatapianiu” receptora w struktury błony komórkowej, przez co staje się on mniej dostępny dla agonistów. Dimeryzacja polega na tworzeniu się kompleksów złożonych z dwóch receptorów, które działają „jakby wspólnie”. Do aktywacji takiego kompleksu wymagane jest większe stężenie ligandu w przestrzeni zewnątrzkomórkowej. Podobne dimery tworzą się w obrębie różnych klas receptorów opioidowych, mogą również składać się z receptorów opioidowych i innych receptorów błonowych [31]. Uzasadnia to indywidualizację leczenia, ponieważ te same leki mogą działać inaczej u różnych pacjentów, również skuteczność analgetyczna opiodów może zmieniać się w czasie.

Nadal kontrowersyjne pozostaje podawanie jednocześnie różnych leków z grupy opiodów. Wątpliwości co do zasadności takiego postępowania spowodowane były tym, że wszystkie leki z tej grupy mają podobny punkt uchwytu w postaci receptora opioidowego. Efekt antynocyceptywny łączono głównie z receptorem $\mu$, natomiast obecnie udowodniono, że wiele leków działa przez receptory $\delta$ lub $\kappa$ albo wykazuje aktywność wobec wielu głównych klas receptorów. Zmianę podejścia do tego problemu spowodowało również odkrycie podklas receptorów opioidowych, co wywołało przypuszczenie, że różnice skuteczności różnych leków w terapii przeciwbólowej mogą być spowodowane powinowactwem do innych odmian tego samego receptora. W ten sposób próbuje się tłumaczyć zasadność zmiany opioidu na inny przy braku działania przeciwbólowego. Równie ważny, bo uzupełniający powyższe doświadczenia, wniosek można wyciągnąć z badania Bolan i wsp., w którym podczas podawania kilku opioidów jednocześnie obserwowano efekt addycyjny [32]. Jeżeli więc opioidy działają przez różnorodne klasy receptorów opioidowych, to uzasadnione jest założenie, że podawanie kilku leków z tej grupy jednocześnie może wywoływać potencjalizację ich działania.

Ostatnio opublikowana praca na modelach zwierzęcych może dawać pewne wskazówki ułatwiające wybór opioidu. Minami i wsp. badali skuteczność działania analgetycznego morfiny, oksykodonu i fentanylu zarówno w bólu spowodowanym przerzutami do kości, jak i w bólu neuropatycznym [33]. 
Wyniki doświadczenia wskazują na dużą skuteczność wszystkich trzech opioidów w modelu bólu w przebiegu przerzutów do kości. Podczas obserwacji prowadzonych podczas sukcesywnego zwiększania podawanych dawek, oksykodon wykazywał wprawdzie nieco silniejsze działanie antynocyceptywne, ale w tym przypadku różnice nie pozwalają na wyraźne preferowanie tego opioidu w omawianym wskazaniu. Opisywana część eksperymentu rzuca nowe światło również na problemy stosowania opioidów w bólu kostnym. Istnieje wśród niektórych lekarzy praktyków przekonanie, że fentanyl jest znacząco mniej skuteczny w tym przypadku. Autorzy wykazali zależne od dawki zmiany odczuwania bólu przez zwierzęta doświadczalne w przypadku wszystkich badanych leków, nie można więc podtrzymać tezy, jakoby fentanyl w tym przypadku nie miał działania analgetycznego.

W omawianej publikacji przedstawiono również ciekawe porównanie wpływu badanych leków na zależne od dawki zachowania unikowe i zachowania związane z alodynią. Najkorzystniejszy profil działania odnotowano w przypadku oksykodonu, wykazując zależności prawie liniowe we wszystkich ocenianych parametrach, czego nie stwierdzono ani w przypadku morfiny, ani w przypadku fentanylu.

W drugiej części eksperymentu oceniano wpływ badanych leków na odczuwanie bólu neuropatycznego. W tym przypadku najskuteczniejszy okazał się oksykodon, najsilniej hamujący doznania bólowe wywołane stymulowaniem łapy zwierzęcia filamentem von Freya, jak również znacznie zmniejszający zachowania unikowe. Różnice skuteczności działania stwierdzone między grupami leczonymi za pomocą oksykodonu, morfiny i fentanylu były w przypadku leczenia zespołów bólu neuropatycznego o wiele większe niż podczas badania modelu przerzutu do kości.

Dopuszczalne jest na podstawie powyższych badań wysnucie wniosku, że oksykodon powinien być brany pod uwage jako lek pierwszego rzutu przy wyborze opioidu w mieszanych zespołach bólowych z komponentem neuropatycznym. Należy jednak zaznaczyć, że omawiana praca dotyczy modelu zwierzęcego, powinna być więc traktowana jako wskazówka do dalszych badań, a wnioski wiążące będzie można wyciągnąć dopiero po stwierdzeniu, czy podobną skuteczność odnotowuje się w badaniach klinicznych.

Silniejsze działanie oksykodonu w bólu neuropatycznym można również tłumaczyć jego powinowactwem do receptorów opioidowych $\kappa$. Podczas doświadczeń modelowych bólu neuropatycznego Xu i wsp. stwierdzili zwiększenie pronocyceptywnego działania dynorfin, będących endogennymi ligandami tego receptora [34]. Można więc przypuszczać, że również w przypadku bólu neuropatycznego wywołanego chemioterapią specyficzne działanie tego leku poprzez aktywowanie receptorów $\kappa$ może powodować zmniejszenie dolegliwości. Podobne wnioski wyciąga Núñez [29], oceniając dość krytycznie skuteczność fentanylu w leczeniu bólu neuropatycznego w przebiegu choroby nowotworowej i podkreślając, że oksykodon może być uważany za opioid pierwszego rzutu w tym wskazaniu [29]. Potwierdza to również publikacja García de Paredes i wsp. przedstawiająca wyniki obserwacji dużej grupy pacjentów, których leczono opioidami w takim samym wskazaniu [35].
Z racji tego jednak, że jest to badanie obserwacyjne, nie może być traktowane na poziomie EBM.

W roku obecnym opublikowano wytyczne dotyczące leczenia szpiczaka mnogiego. To zbiorcze opracowanie zawiera wskazówki zarówno co do leczenia zasadniczego, jak i objawowego. W części poświęconej leczeniu bólu w przebiegu tej jednostki chorobowej autorzy podtrzymują stanowisko cytowanych wyżej badaczy, pozycjonując oksykodon jako lek pierwszego rzutu w leczeniu bólu neuropatycznego o różnych etiologiach, a więc także przy CIPN [25].

\section{Podsumowanie}

Brak badań dotyczących stosowania opiodów w CIPN powoduje, że wnioski na temat ich skuteczności można wysnuwać jedynie per analogiam.

Na podstawie dostępnej literatury dotyczącej doświadczeń modelowych i obserwacji klinicznych można stwierdzić, że opioidy są ważnymi składnikami w terapii złożonej w przypadku bólu neuropatycznego, a zatem skuteczne również podczas leczenia CIPN.

Powinowactwo do receptorów błonowych jest jednym z warunków działania analgetycznego leków opioidowych. Różnorodność tych białek i ich podklas warunkuje różną skuteczność ich ligandów, co uzasadnia zarówno rotację opioidów, jak i ich łączenie.

Spośród czystych agonistów receptora opioidowego najsilniejszym działaniem analgetycznym w bólu neuropatycznym wykazał się oksykodon.

\section{Piśmiennictwo}

1. Tofthagen C, Overcash J, Kip K. Falls in persons with chemotherapy-induced peripheral neuropathy. Support Care Cancer 2011; [Epub ahead of print].

2. Kanavos P. The rising burden of cancer in the developing world. Ann Oncol 2006; 17 (suppl. 8): 15-23.

3. Brzeziński K. Ból przewlekły w praktyce lekarza rodzinnego. Cz. III. Ból neuropatyczny. Medycyna Ogólna 2003; 9: 158-65.

4. Dworkin RH, O'Connor AB, Audette J, et al. Recommendations for the pharmacological management of neuropathic pain: an overview and literature update. Mayo Clin Proc 2010; 85 (suppl): 3-14.

5. Dworkin RH, O'Connor AB, Backonja M, et al. Pharmacologic management of neuropathic pain: Evidence-based recommendations. Pain 2007; 13: 2237-251.

6. Finnerup NB, Otto M, McQuay HJ, Jensen TS, Sindrup SH. Algorithm for neuropathic pain treatment: an evidence based proposal. Pain 2005; 118: 289-305.

7. Finnerup NB, Sindrup SH, Jensen TS. The evidence for pharmacological treatment of neuropathic pain. Pain 2010; 150: 573-81.

8. Stępień A, Domżał TM. Nowe wytyczne dotyczące leczenia bólu neuropatycznego. New guidelines for the treatment of neuropathic pain. Neurol Neurochir Pol 2010; 44: 437-42.

9. Brzeziński K, Sodolski W, Horoch A. Zastosowanie gabapentyny i tramadolu w leczeniu neuralgii popółpaścowej. Doniesienie wstępne. Polska Medycyna Paliatywna 2004; 3: 21-5.

10. Evidence-based chronic pain management. Stannard CF, Kalso E, Ballantyne J (eds.). Wiley-Blackwell 2010.

11. Jost L, Roila F. Management of cancer pain: ESMO Clinical Recommendations. Ann Oncol 2009; 20 (suppl. 4): 170-3.

12. Bilińska M, Usnarska-Zubkiewicz L, Dmoszyńska A. Polineuropatia wywołana talidomidem i bortezomibem u chorych na szpiczaka mnogiego, możliwości leczenia bólu neuropatycznego. Zalecenia Polskiej Grupy Szpiczakowej. Wspolczesna Onkol 2008; 12: 441-6. 
13. Reddy GK, Mughal TI, Lonial S, Optimizing the management of treatment-related peripheral neuropaty In patients with multiple myeloma. Supp Cancer Ther 2006; 4: 19-22.

14. Umapathi T, Chaudhry V. Toxic neuropathy. Curr Opin Neurol 2005; 18: 574-80.

15. Kirchmair R, Walter DH, li M, et al. Antiangiogenesis mediates cisplatin-induced peripheral neuropathy: attenuation or reversal by loca vascular endothelial growth factor gene therapy without augmenting tumor growth. Circulation 2005; 111: 2662-70.

16. Albers J, Chaudhry V, Cavaletti G, Donehower R. Interventions for preventing neuropathy caused by cisplatin and related compounds (Review). The Cochrane Library 2008; Issue 4.

17. Paice JA. Chronic treatment-related pain in cancer survivors. Pain 2011; 152: 84-89.

18. Attal N, Cruccu G, Baron R, Haanpaa M, Hansson P, Jensen TS. EFNS guidelines on the pharmacological treatment of neuropathic pain: 2010 revision. Europ J Neurol 2010; 17: 1113-33.

19. Attal N. Management of neuropathic cancer pain. Ann Oncol 2010; 21: 1134-35.

20. Furlan AD, Sandoval AS, Gagnon AM, Tunks E. Opioids for chronic noncancer pain: a meta-analysis of effectiveness and side effects. CMAJ 2006; 174: 1589-94.

21. Simone CB 2nd, Vapiwala N, Hampshire MK, Metz JM. Cancer patient attitudes toward analgesic usage and pain intervention. Clin J Pain 2011; [Epub ahead of print].

22. Eisenberg E, McNicol ED, Carr DB. Efficacy and safety of opioid ago nists in the treatment of neuropathic pain of nonmalignant origin systematic review and meta-analysis of randomized controlled trials. JAMA 2005; 293: 3043-52.

23. Eisenberg E, McNicol ED, Carr DB. Opioids for neuropathic pain. The Cochrane Library 2009; Issue 1.

24. Kaley TJ, DeAngelis LM. Therapy of chemotherapy-induced peripheral neuropathy. Br J Haematol 2009; 145: 3-14.

25. Snowden JA, Ahmedzai SH, Ashcroft J, et al. Guidelines for supportive care in multiple myeloma 2011. Br J Haematol 2011; 154: 76-103.

26. Takase H, Sakata T, YamanoT, Sueta T, Nomoto S, Nakagawa T. Advantage of early induction of opioid to control pain induced by irradiation in head and neck cancer patients. Auris Nasus Larynx 2011; 4: 495-500.

27. Dzierżanowski T, Ciałkowska-Rysz A. Neuropathic pain in palliative care patients. Medycyna Paliatywna 2010; 2: 57-66.

28. Mizoguchi H, Watanabe C, Yonezawa A, Sakurada S. New therapy for neuropathic pain. Int Rev Neurobiol 2009; 85: 249-60.

29. Nunez Olarte JM. Oxycodone and the challenge of neuropathic cancer pain: a review. Oncology 2008; 74: 83-90.

30. Urban JD, Clarke WP, von Zastrow M, et al. Functional selectivity and classical concepts of quantitative pharmacology. J Pharmacol Exp Ther 2007; 320: 1-13.

31. Keith DE, Anton B, Murray SR, et al. mu-Opioid receptor internalization: opiate drugs have differential effects on a conserved endocytic mechanism in vitro and in the mammalian brain. Mol Pharmacol 1998; 53: 377-84.

32. Bolan E, Tallarida RJ, Pasternak GW. Synergy between mu opioid ligands: evidence for functional interactions among mu opioid receptor subtypes. J Pharmacol Exp Ther 2002; 303: 557-62.

33. Minami K, Hasegawa M, Ito H, et al. Morphine, oxycodone, and fentanyl exhibit different analgesic profiles in mouse pain models. J Pharmacol Sci 2009; 111: 60-72.

34. Xu M, Petraschka M, McLaughlin JP, Westenbroek RE, Caron MG, Lefkowitz RJ, Czyzyk TA, Pintar JE, Terman GW, Chavkin C. Neuropathic pain activates the endogenous $\kappa$ opioid system in mouse spinal cord and induces opioid receptor tolerance. J Neurosci 2004; 24: 4576-84.

35. Garcl'a de Paredes ML, Gonzalez F, P. Prado PM, Ciriquian JLM, Frances SE, Dols MC, Gonzalez EE, Granados ALO, Tarruella MM, Buron JDC, Hernandez AG, E. Miranda L, Santos JPC, Carpeño FJC. First evidence of oncologic neuropathic pain prevalence after screening 8615 cancer patients. Results of the on study. Ann Oncol 2011; 22: 924-30.

\section{Addres do korespondencji}

\section{Krzysztof Brzeziński}

Instytut Medycyny Wsi

ul. Jaczewskiego 2

20-950 Lublin

tel. 605228412

e-mail: k.brzezinski@op.pl 